\title{
Perumusan Kebijakan dan Peraturan Daerah Dengan Mekanisme Konsultasi Publik
}

\author{
Armen Yasir dan Zulkarnain Ridlwan
}

Dosen Bagian Hukum Tata Negara Fakultas Hukum Universitas Lampung

\begin{abstract}
Abstrak
Tujuan penulisan ini adalah untuk mendeskripsikan pentingnya ketersediaan mekanisme konsultasi publik dalam perumusan kebijakan dan peraturan ditingkat daerah. Berdasarkan tinjauan normatif, disimpulkan bahwa tersedianya mekanisme konsultasi publik sangat penting guna membangun keterlibatan masyarakat sekaligus membentuk keterbukaan lembaga publik. Kondisi yang demikian selaras dengan prinsip negara hukum. Guna menjamin efektifitas mekanisme tersebut, maka daerah perlu mengundangkan peraturan daerah yang mengatur akan hal itu.
\end{abstract}

Kata Kunci : Payung Hukum, Mekanisme Konsultasi Publik, di Daerah

\section{Pendahuluan}

Pelibatan masyarakat dalam perumusan kebijakan telah menjadi diskursus intensif dalam pengelolaan pemerintahan dewasa ini. Pelibatan ini dimaksudkan untuk membentuk sinergi kemitraan antara pemerintah dan publik dalam penyusunan kebijakan publik sekaligus menjalankan prinsip demokratisasi dalam proses formulasi kebijakan publik. Keterlibatan publik tersebut terutama dalam fase perumusan kebijakan, sebab yang terpenting dalam proses kebijakan publik adalah formulasi (perumusan) kebijakan ${ }^{1}$.

oleh $\begin{array}{ccr}\text { Sebagaimana } \\ \mathrm{Leo}^{2}\end{array}$ dalam $\begin{array}{r}\text { dikemukakan } \\ \text { menjelaskan }\end{array}$ paradoksal antara nilai demokrasi dan birokrasi, bahwa demokratisasi dalam proses formulasi kebijakan publik dapat dipahami sebagai akomodasi kepentingan masyarakat dalam

\footnotetext{
${ }^{1}$ Lihat Leo Agustio, Dasar-dasar Kebijakan Publik, (Bandung: Alfabeta, 2008), hlm. 96.

${ }^{2}$ Ibid.,hlm. iv.
}

kebijakan serta adanya partisipasi masyarakat dalam proses pembuatan kebijakan publik. Namun pada kenyataannya partisipasi dan akomodasi kepentingan publik seringkali terbentur dengan nilai-nilai prosedural hirarkis-birokratis-formal yang menyebabkan proses formulasi seakan-akan berada dalam ruang terbuka akan tetapi sarat dengan muatan birokratis yang memunculkan nilai demokratis semu, ersazt democracy.

Pilihan model formulasi kebijakan cukup banyak. Thomas R. Dye dalam bukunya Understanding Public Policy (1995) sebagaimana dikutip oleh $\mathrm{Leo}^{3}$ menjabarkan setidaknya terdapat sembilan model formulasi kebijakan, yaitu: model sistem, model elite, model institusional, model kelompok, model proses, model rasional, model inkremental, model pilihan publik, dan model teori permainan. Dari sembilan model tersebut, model elite dan model

\footnotetext{
${ }^{3}$ Ibid.,hlm. 131.
} 
pilihan publik menjadi sampel perbedaan yang sangat timpang.

Dalam model elite tergambar jelas bagaimana kebijakan yang dihasilkan hampir dapat dipastikan akan berwarna kepentingan elite-elite yang berkuasa dibandingkan dengan kebutuhan dan tuntutan publik. Karena pada dasarnya ketika para elite merumuskan kebijakan, maka kebijakan-kebijakan yang berusaha untuk mempertahankan kekuasaannya, kebijakan yang menguntungkan dirinya, hingga kebijakan yang berusaha meminggirkan partisipasi publik akan lebih banyak muncul. ${ }^{4}$ Adapun model pilihan publik, menyatakan bahwa kebijakan yang dibuat oleh pemerintah haruslah kebijakan yang memang berbasis pada public choices (pilihan publik yang mayoritas).

Dari kedua model formulasi kebijakan tersebut, pilihan yang lebih tepat adalah model pilihan publik. Model ini menjabarkan pelibatan masyarakat dalam penyusunan kebijakan publik dengan membuka kesempatan yang luas. Disatu sisi dapat terlihat dalam keseharian, keinginan masyarakat untuk melibatkan diri semakin menguat seiring semakin meningkatnya kesadaran dan kemampuan untuk bertumbuh, berdaya, dan berkembang menjadi civil society. Masyarakat semakin paham akan hak dan kewajiban mereka dalam pengelolaan persoalan-persoalan publik.

Oleh sebab itu, partisipasi publik dalam proses pemerintahan dan pembangunan perlu ditegaskan sebagai upaya yang paling efektif dalam konteks penciptaan good governance, karena di dalamnya ada pelibatan seluruh stakeholders, pemberian legitimasi, transparansi, nilai keadilan, dan akuntabilitas. Media untuk menjamin partisipasi publik tesebut dikenal dengan istilah mekanisme kebijakan publik. Media ini dilindungi oleh aturan hukum guna dimanfaatkan publik dalam mengakses informasi, memberikan masukan dalam penentuan kebijakan publik dan perencanaan, pelaksanaan, pemantauan dan evaluasi agenda pembangunan serta pelaksanaan tugas oleh badan publik.

Penyusunan kebijakan publik yang dimaksud disini termasuk kebijakan publik ditingkat daerah dalam bentuk Peraturan Daerah (Perda). Perda yang merupakan produk kebijakan yang sangat penting ditingkat daerah haruslah dapat dipertanggungjawabkan kepada seluruh pemangku kepentingannya. Masyarakat sebagai pemangku kepentingan Perda hendaknya dapat diberi kesempatan untuk ikut menentukan arah dan substansi kebijakan selama tidak bertentangan dengan kebijakan umum ditingkat nasional dan sejalan dengan peraturan perundang-undangan yang berlaku.

Mekanisme keterlibatan inilah yang penting untuk diatur dalam suatu peraturan legal formal agar dalam prakteknya tidak lagi ada keraguan masyarakat akan pentingnya peran serta dalam pemerintahan. Disisi lain ketersediaan mekanisme pelibatan ini akan memberi format baru dalam penyelenggaraan pemerintahan daerah, dalam hal ini pengelolaan badan publik, untuk senantiasa memerhatikan kedudukan masyarakat dalam perumusan kebijakan. Sehingga cita untuk menciptakan pemerintahan daerah yang sejalan dengan asas-asas

${ }^{4}$ Ibid.,hlm. 132. 
umum pemerintahan yang baik akan dapat terwujud.

\section{Konsultasi Publik dalam Prinsip Negara Hukum dan Demokrasi}

Konsep negara hukum yang demokratis menggariskan bahwa keberadaan peraturan perundangundangan, termasuk peraturan daerah, dibuat untuk mewujudkan prinsipprinsip dasar negara hukum itu sendiri. Peraturan perundang-undangan sebagai bentuk formil hukum juga diarahkan kepada hal tersebut, hak masyarakat dijamin dan dilindungi dengan peraturan perundang-undangan.

Hubungan antara demokrasi dan negara hukum dapat tercermin dalam penjabaran bahwa yang dapat menjamin secara konstitusional terselenggaranya pemerintah yang demokratis adalah adanya hukum yang menaunginya. Dengan kata lain demokrasi yang berada dibawah Rule of Law. Sedangkan syarat-syarat dasar untuk terselenggaranya pemerintahan yang demokratis di bawah Rule of Law ialah: ${ }^{5}$

1. Perlindungan konstitusional, dalam arti bahwa konstitusi, selain menjamin hak-hak individu, harus menentukan pula cara prosedural untuk memperoleh perlindungan atas hak-hak yang dijamin.

2. Badan kehakiman yang bebas dan tidak memihak (independent and impartial tribunals).

3. Pemilihan umum yang bebas.

4. Kebebasan untuk menyatakan pendapat.

5. Kebebasan untuk berserikat/berorganisasi dan beroposisi.

\footnotetext{
${ }^{5}$ Miriam Budiardjo, Dasar-Dasar Ilmu Politik, (Edisi Revisi), (Jakarta: PT Gramedia Pustaka Utama, 2008), hlm. 116.
}

6. Pendidikan kewarganegaraan (civic education).

Ketersediaan mekanisme konsultasi publik dalam pembentukan kebijakan di daerah sejalan dengan perlindungan konstitusional sebagai salah satu syarat dasar pemerintahan demokratis. Urgensitas penerapan mekanisme konsultasi publik dewasa ini juga sejalan dengan prinsip demokrasi. Held mengemukakan 7 prinsip demokrasi yang paling utama yaitu:

1. That all should govern, in the sence that all should be involved in legislating, in deciding in general policy, in apllying laws in the government administration.

2. That all should be personally involved in crucial decision making, that is to say in deciding general laws and matters of general policy.

3. The rulers should be accountable to the ruled: They should, in other words, be obligated to justify their action to the ruled and be removable by the ruled.

4. The rulers should be accountable to the representatives to the ruled.

5. That rulers should be chosen by the ruled.

6. That rulers should be chosen by the representatives of the ruled.

7. The rulers should act in the intres of the ruled.

Konsultasi publik dalam hal ini dapat digolongkan menjadi bentuk akuntabilitas dan petanggungjawaban tindakan yang dilakukan pemerintah. Dengan demikian, disamping sejalan dengan cita negara hukum, keberadaan

6 Miriam Budiardjo, dan Ambong, Fungsi Legislatif dalam Sistem Politik Indonesia, Rajawali Press, Jakarta, 1995, hlm. 74 mengutip dari David Held, Models of Democracy, Politiy Press, London, 1990. 
mekanisme konsultasi publik sesuai dengan prinsip demokrasi. Meski dalam prakteknya, demokrasi ditakdirkan untuk bersifat illusive dan imposible. Illusive sebab elit sebenarnya hanya bertanggung jawab diantara mereka sendiri, tidak pernah langsung ke rakyat. Imposible sebab elite, sekali terpilih mewakili rakyat dalam pemilu, dapat dengan mudah mengatasnamakan kepentingan pribadi (personal interest) sebagai kehendak rakyat (the will of the people). ${ }^{7}$

\section{Landasan Penerapan Mekanisme Konsultasi Publik ditingkat Daerah}

Kebijakan dan peraturan daerah dibuat atas dasar tujuan-tujuan tertentu yang ingin dicapai yang dilandaskan pada pedoman atau standar norma yang digariskan oleh pemerintah. Perda sebagai instrumen penyelenggaraan kekuasaan pemerintah daerah harus mempunyai karakter yang menghormati, melindungi dan memenuhi hak-hak masyarakat. Karakter pengaturannya pun harus bersifat progresif, artinya pengaturan tetap harus memahami kondisi sosial ekonomi masyarakat. Proses pembentukan Perda secara rigid diatur dalam Pasal 136 Undang-Undang Nomor 32 tahun 2004 yang menentukan bahwa:

(1) Perda ditetapkan oleh kepala daerah setelah mendapat persetujuan bersama DPRD.

(2) Perda dibentuk dalam rangka penyelenggaraan otonomi daerah provinsi/ kabupaten/kota dan tugas pembantuan.

(3) Perda sebagaimana dimaksud pada ayat (1) merupakan penjabaran lebih lanjut dari peraturan perundang-undangan yang lebih

\footnotetext{
7 John Plamenatz, Democracy and Illusion, Longman, New York, 1976.
}

tinggi dengan memperhatikan ciri khas masing-masing daerah.

(4) Perda sebagaimana dimaksud pada ayat (1) dilarang bertentangan dengan kepentingan umum dan/atau peraturan perundangundangan yang lebih tinggi.

(5) Perda sebagaimana dimaksud pada ayat (1), berlaku setelah diundangkan dalam lembaran daerah.

Berdasarkan Pasal 137 UndangUndang Nomor 32 tahun 2004 ditentukan bahwa Perda dibentuk berdasarkan pada asas pembentukan peraturan perundang-undangan yang meliputi:

a) kejelasan tujuan; artinya, tujuan dari perda yang akan dibentuk tidak menyimpang dari tujuan yang telah digariskan dalam dasar filosofis, yuridis dan sosiologis dalam pembentukan Perda.

b) kelembagaan atau organ pembentuk yang tepat; artinya, perda ini dapat dibentuk atas usulan Dewan Perwakilan Rakyat Daerah (hak inisiatif lembaga legislatif) atau oleh Kepala Daerah. Perda dibahas bersama antara lembaga legislatif dengan lembaga eksekutif, dan atas persetujuan bersama antara keduanya, kepala daerah menetapkan perda.

c) kesesuaian antara jenis dan materi muatan; artinya, materi muatan yang terkandung dalam perda yang akan dibentuk berkesesuaian dengan jenis perdanya.

d) dapat dilaksanakan; artinya, perda yang akan dibentuk akan menjadi pedoman perilaku bagi semua pihak serta ketentuan pasal/norma dalam perda dapat diimplentasikan/operasional.

e) kedayagunaan dan kehasilgunaan; artinya perda yang akan dibentuk 
dapat diterima baik secara filosofis, sosiologis dan yuridis.

f) kejelasan rumusan; artinya bahwa rumusan pasal dapat dipahami dan dilaksanakan dan tidak menimbulkan tafsir ganda (ambigu).

g) keterbukaan; artinya, peran serta masyarakat dapat diakomodasi baik dalam proses penyusunan, pelaksanaan maupun pengawasan.

Mekanisme konsultasi publik sejalan dengan asas keterbukaan. Dalam konteks proses pembentukan Perda, kesepakatan atau persetujuan bersama antara kepala daerah dan DPRD dengan menegasikan keterlibatan masyarakat/publik sebagai stakeholders bukanlah kondisi yang tepat. Realitas keberadaan pemerintah daerah yang sejatinya sebagai pelayan masyarakat hendaknya menyadarkan institusi tersebut untuk melibatkan seluruh pihak yang terkait dalam urusan publik melalui forum-forum terbuka seperti, media massa, public hearing, forum warga, dan forum masyarakat luas lainnya. Metode seperti ini akan memungkinkan institusi-institusi pemerintahan dapat mengetahui seluruh aspirasi masyarakat dan mengartikulasikannya dalam setiap aktivitas pemerintahan dan pembangunan. Disamping itu dengan adanya media tersebut, maka seluruh kelompok kepentingan yang ada dalam masyarakat juga diharapkan dapat menciptakan keseimbangan dalam menengahi keberagaman pikiran atau konflik yang ada. Situasi seperti ini akan menciptakan peluang potensial bagi masyarakat luas untuk menjalankan kewajiban maupun haknya secara legal dan bertanggung jawab. ${ }^{8}$

$\begin{array}{lll}8 \text { Lijan } & \text { Poltak } & \text { Sinambela, Reformasi } \\ \text { Pelayanan } & \text { Publik; } & \text { teori, kebijakan, dan }\end{array}$
Konsultasi publik (public consultation) bersama dengan istilah dengar pendapat umum (public hearing) adalah dua istilah yang menjadi popular dengan berkembangnya proses-proses partisipatif dalam penentuan kebijakan dan perumusan/ penyusunan peraturan perundang-undangan yang tentunya akan berdampak bagi warganegara. Konsultasi publik merupakan istilah yang sering terkait dengan proses yang dilakukan oleh eksekutif, sedangkan dengar pendapat umum lebih sering terkait dengan proses yang dilakukan di gedung dewan oleh kalangan legislatif. Meskipun sebenarnya legislatif juga dapat melakukan konsultasi publik di daerah-daerah untuk memperoleh masukan mengenai suatu rancangan peraturan perundangundangan yang sedang disusunnya. Konsultasi Publik yang dilakukan pemerintah untuk melibatkan warga negara dalam merumuskan sebuah kebijakan atau peraturan akan membangun terjadinya hubungan dua arah antara pemerintah dan warganegara. Di sini, peran penting warganegara dan para pemangku kepentingan (stakeholders) lain diakui oleh pemerintah. ${ }^{9}$

Pernyataan bahwa "ada hak masyarakat untuk memberikan masukan dalam setiap kebijakan

implementasi, (Jakarta: Bumi Aksara, 2007), hlm. 47-48.

9 Pengantar Resensi buku Memfasilitasi Kebijakan Publik; Refleksi Pengalaman Penyusunan Rancangan Peraturan Pemerintah tentang Tahapan, Tata Cara Penyusunan, Pengendalian, dan Evaluasi Pelaksanaan Rencana Pembangunan Daerah (RPP$T 2 C P 2 E P R P D)$ yang diterbitkan oleh FPPM, BIGS, USAID-DRSP dan Dirjen Bina Bangda Depdagri. Sebagaimana dipublikasikan dalam http://jrki.wordpress.com/category/resensibuku/. 
negara"10 melekat pada penyelenggaraan pemerintahan dalam seluruh tingkatannya, termasuk dalam penyelenggaraan pemerintahan daerah. Bentuk operasional dari pemberian masukan masyarakat tersebut lazim dikenal dengan istilah konsultasi publik. Konsultasi publik digunakan sebagai salah satu dari metode-metode partisipatif dalam merancang dan memutuskan sebuah kebijakan bersama eksekutif. Konsultasi publik tidak lain adalah musyawarah antara warganegara dan pemerintah untuk mencari cara terbaik atau untuk memecahkan suatu persoalan. Melalui konsultasi publik, relasi antar warga negara dan pemerintah dikembangkan menjadi hubungan yang lebih erat, sejajar dan saling memerlukan satu sama lain.

Keterlibatan masyarakat dalam penyusunan kebijakan di wilayah eksekutif biasanya jarang terjadi. Pihak eksekutif (juga legislatif) umumnya jarang memberikan ruang bagi publik untuk terlibat dalam perumusan kebijakan. Demikian pula yang berjalan di pemerintahan daerah. Keterbukaan pemerintah daerah atas masukan dan pendapat publik dalam penyusunan kebijakan daerah belum disediakan mekanisme yang jelas. Mekanisme yang dimaksud disini yaitu suatu prosedur yang legal formal diatur dalam peraturan daerah berkaitan dengan tata cara masyarakat untuk melibatkan diri dalam penyusunan kebijakan publik.

Ketiadaan mekanisme ini menjadikan masyarakat hanya memiliki sarana komunikasi guna memberi masukan kepada pemerintah daerah melalui sarana media massa. Baik media cetak yang berupa koran lokal, maupun media elektronik yang

${ }^{10}$ Pengantar Resensi Buku, Op.Cit. berupa televisi dan radio lokal, serta media online. Akan tetapi sarana tersebut belum memberi peluang bagi didengar atau diperhatikannya masukan/pendapat masyarakat akan suatu perumusan kebijakan. Bahkan yang lebih tidak efektif adalah tidak adanya itikad baik dari pemerintah daerah untuk memperhatikan sama sekali. Bisa jadi hal ini disebabkan keterbatasan pemahaman dan teknik mengelola masukan dari masyarakat, baik dikalangan eksekutif maupun legislatif. Namun juga bisa disebabkan kurang efektifnya sarana dan mekanisme pengajuan pendapat publik tersebut.

Padahal dalam Pasal 5 UndangUndang Nomor 12 Tahun 2011 tentang Pembentukan Peraturan Perundangundangan dinyatakan bahwa salah satu asas pembentukan peraturan perundang-undangan yang baik adalah "asas keterbukaan" (huruf g) yang selanjutnya dalam penjelasannya dinyatakan bahwa: "dalam proses pembentukan peraturan perundangundangan mulai dari perencanaan, persiapan, penyusunan, dan pembahasan bersifat transparan dan terbuka. Dengan demikian seluruh lapisan masyarakat mempunyai kesempatan yang seluas-luasnya untuk memberikan masukan dalam proses pembuatan peraturan perundangundangan.

Implementasi dari asas keterbukaan adalah dalam bentuk peran serta masyarakat sebagaimana diatur dalam Pasal 96 Undang-Undang Nomor 12 Tahun 2011 yang berbunyi: "Masyarakat berhak memberikan masukan secara lisan dan/atau tertulis dalam pembentukan perundangundangan."

Berdasarkan ketentuan dalam

Pasal 28 (Rancangan) Peraturan Presiden tentang Tata Cara Mempersiapkan Rancangan Peraturan 
Daerah sebagai pelaksanaan Pasal 59 Undang-Undang Nomor 12 Tahun 2011 tentang Pembentukan Peraturan Perundangundangan dan Pasal 140 ayat (3) Undang-Undang Nomor 32 Tahun 2004 tentang Pemerintahan Daerah dinyatakan bahwa: ${ }^{11}$

(1) Masyarakat berhak memberikan masukan secara lisan atau tertulis sebagai bahan penyempurnaan dalam tahap penyiapan rancangan Perda.

(2) Masyarakat dalam memberikan masukan harus menyebutkan identitas secara lengkap dan jelas.

(3) Masukan sebagaimana dimaksud pada ayat (1), memuat pokokpokok materi yang diusulkan.

(4) Masukan dari masyarakat sebagaimana dimaksud pada ayat (1), dapat diagendakan dalam rapat penyiapan rancangan Perda.

Dalam proses penyusunan Rancangan Peraturan Daerah baik di lingkungan Pemerintah Daerah maupun di DPRD masyarakat tetap dapat berperan serta secara aktif untuk memberikan masukan dalam penyempurnaan Rancangan Peraturan Daerah, demikian juga pada saat dilakukan pembahasan bersama antara DPRD dan Pemerintah Daerah, DPRD dapat menyelenggarakan Rapat Dengar Pendapat Umum untuk mendapatkan lagi masukan dari masyarakat.

11 Kementerian Hukum dan Hak Asasi Manusia Republik Indonesia, Direktorat Jenderal Peraturan Perundang-undangan, Direktorat Fasilitasi Perancangan Peraturan Daerah, Panduan Praktis Memahami Perancangan Peraturan Daerah, Edisi Kelima, (Jakarta: Direktorat Jenderal Peraturan Perundang-undangan, 2011), hlm., 18-19. Lihat juga Departemen Hukum dan Hak Asasi Manusia RI Direktorat Jendral Peraturan Perudang-Undangan bekerja sama dengan United Nations Development Programme (UNDP), Panduan Praktis Memahami Perancangan Peraturan Daerah, (Jakarta: CAPPLER Project, 2008), hlm. 15.
Peran serta masyarakat dalam proses penyusunan Peraturan Daerah dilaksanakan dengan memperhatikan prinsip akses informasi dan partisipasi.

1) Akses Informasi

Dalam rangka akses informasi, Pemerintahan Daerah wajib menyebarluaskan rancangan atau peraturan perundang-undangan tingkat daerah. Penyebarluasan bagi Peraturan Daerah dan Peraturan perundangundangan dibawahnya dilakukan sesuai dengan perintah Pasal 94 Undang Undang Nomor 12 Tahun 2011 tentang Pembentukan Peraturan perundangundangan yang menyatakan bahwa "Penyebarluasan Peraturan Daerah Provinsi atau Peraturan Daerah Kabupaten/Kota yang telah diundangkan dalam Lembaran Daerah dilakukan bersama oleh DPRD dan Pemerintah Daerah Provinsi atau Kabupaten/Kota."

Penyebarluasan dimaksudkan agar khalayak ramai mengetahui peraturan perundang-undangan di daerah yang bersangkutan dan mengerti/memahami isi serta maksud yang terkandung di dalamnya. Penyebarluasan dapat dilakukan melalui media elektronik, atau media cetak yang terbit di daerah yang bersangkutan serta media komunikasi langsung.

\section{2) Akses Partisipasi}

Mengenai partisipasi publik dalam Undang Undang Nomor 12 Tahun 2011 tentang Pembentukan Peraturan Perundang-undangan telah diatur secara tegas dalam Pasal 96 yang menyatakan bahwa masyarakat berhak memberikan masukan secara lisan dan/atau tertulis dalam pembentukan peraturan perundangundangan.

Partisipasi masyarakat pada tahap pembahasan di DPRD dapat dilakukan sesuai dengan peraturan tata 
tertib DPRD. Dengan akses partisipasi memungkinkan masyarakat untuk menyampaikan aspirasi atau menyumbangkan pemikirannya terhadap suatu kebijakan yang akan diambil oleh pemerintah daerah. Dalam hal masukan disampaikan secara lisan, maka yang bersangkutan dapat menyampaikan sendiri kecuali dalam hal masukan secara lisan disampaikan oleh kelompok masyarakat maka harus diwakilkan pada pimpinan kelompok tersebut.

Akses partisipasi sebagaimana telah diuraikan diatas sejalan dengan kebijakan Menteri Dalam Negeri yang ditetapkan dalam Keputusan Menteri Dalam Negeri Nomor 41 Tahun 2001 tentang Pengawasan Represif terhadap Kebijakan Pemerintah Daerah. Keputusan Menteri tersebut memberikan peluang kepada masyarakat yang merasa haknya dilanggar untuk mengajukan Hak Uji Materiil terhadap Peraturan Daerah ke Mahkamah Agung.

Oleh karena itu, mengantisipasi permasalahan ketidakefektifan pelaksanaan peraturan daerah pada masa yang akan datang, maka dalam setiap pembentukannya diperlukan adanya keterbukaan yaitu pemberian kesempatan kepada masyarakat baik dari unsur akademisi, praktisi, maupun dari unsur masyarakat terkait lainnya untuk berpartisipasi, baik dalam proses perencanaan, persiapan, penyusunan dan/atau dalam pembahasan Raperda dengan cara memberikan kesempatan untuk memberikan masukan atau saran pertimbangan secara lisan atau tertulis sesuai dengan ketentuan peraturan perundang-undangan yang berlaku.

Kajian terhadap peraturan perundang-undangan ini dimaksudkan untuk mengetahui kondisi hukum atau peraturan perundang-undangan yang mengatur mengenai substansi atau materi yang akan diatur. Dalam kajian ini akan diketahui posisi dari peraturan daerah yang baru. Analisis ini akan menggambarkan sinkronisasi, harmonisasi peraturan perundangundangan yang ada serta posisi dari peraturan daerah untuk menghindari terjadinya tumpang tindih pengaturan.

1) Undang-Undang Nomor 9 Tahun 1998 Tentang Kemerdekaan Menyampaikan Pendapat di Depan Umum

Kemerdekaan menyampaikan pendapat tersebut sejalan dengan Pasal 9 Deklarasi Universal Hak-hak Asasi Manusia yang berbunyi "Setiap orang berhak atas kebebasan mempunyai dan mengeluarkan pendapat, dalam hal ini termasuk kebebasan mempunyai pendapat dengan tidak mendapat gangguan dan untuk mencari, menerima dan menyampaikan keterangan dan pendapat dengan cara apa pun juga dan dengan tidak memandang batas-batas".

Perwujudan kehendak warga negara secara bebas dalam menyampaikan pikiran secara lisan dan tulisan dan sebagainya harus tetap dipelihara agar seluruh tatanan sosial dan kelembagaan baik infrastruktur maupun suprastruktur tetap terbebas dari penyimpangan atau pelanggaran hukum yang bertentangan dengan maksud, tujuan dan arah dari proses keterbukaan dalam pembentukan dan penegakan hukum sehingga tidak menciptakan disintegrasi sosial, tetapi justru harus dapat menjamin rasa aman dalam kehidupan masyarakat.

a. Pasal 2 Ayat (1) Setiap warga negara, secara perorangan atau kelompok menyampaikan pendapat sebagai perwujudan hak dan tanggung jawab berdemokrasi dalam kehidupan bermasyarakat, berbangsa, dan bernegara. 
b. Pasal 4 Huruf c bahwa tujuan pengaturan tentang kemerdekaan menyampaikan pendapat di muka umum adalah mewujudkan iklim yang kondusif bagi berkembangnya partisipasi dan kreativitas setiap warga negara sebagai perwujudan hak dan tanggung jawab dalam kehidupan berdemokrasi.

2) Undang-Undang Nomor 28 Tahun 1999 Tentang Penyelenggara Negara Yang Bersih Dan Bebas Dari Korupsi, Kolusi Dan Nepotisme

Pelibatan masyarakat dalam upaya penyelenggaraan negara yang bersih dan bebas dari KKN, diatur dalam Pasal 3, Pasal 8, Pasal 9, Penjelasan Umum, Penjelasan Pasal 3, Penjelasan Pasal 8, dan Penjelasan Pasal 9.

a. Pasal 3 Asas-asas umum penyelenggaraan negara meliputi :
a) Asas Kepastian Hukum;
b) Asas Tertib Penyelenggaraan Negara;
c) Asas Kepentingan Umum;
d) Asas Keterbukaan;
e) Asas Proporsionalitas;
f) Asas Profesionalitas, dan
g) Asas Akuntabilitas.

b. Khusus mengenai peran serta masyarakat, diatur dalam Bab VI yang terdiri dari Pasal 8 dan Pasal 9.

a) Pasal 8

Ayat (1) Peran serta masyarakat dalam penyelenggaraan negara merupakan hak dan tanggung jawab masyarakat untuk ikut mewujudkan Penyelenggara Negara yang bersih.

Ayat (2) Hubungan antar Penyelenggara Negara dan masyarakat dilaksanakan dengan berpegang teguh pada asas-asas umum penyelenggaraan negara sebagaimana dimaksud dalam Pasal 3. b) Pasal 9

Ayat (1) Peran serta masyarakat sebagaimana dimaksud dalam Pasal 8 diwujudkan dalam bentuk :

1) hak mencari, memperoleh, dan memberikan informasi tentang penyelenggaraan negara;

2) hak untuk memperoleh kekayaan yang sama dan adil dari Penyelenggara Negara;

3) hak menyampaikan saran dan pendapat secara bertanggung jawab terhadap kebijakan penyelenggara negara; dan

4) hak memperoleh perlindungan hukum dalam hal :

a. melaksanakan haknya sebagaimana dimaksud dalam huruf $a, b$, dan c;

b. diminta hadir dalam proses penyelidikan, penyidikan, dan di sidang pengadilan sebagai saksi pelapor, saksi, atau saksi ahli, sesuai dengan ketentuan peraturan perundang-undangan yang berlaku.

Ayat (2) Hak tersebut dilaksanakan sesuai dengan ketentuan peraturan perundang-undangan yang berlaku dan dengan menaati norma agama dan norma sosial lainnya.

\section{c. Penjelasan Umum}

Tindak pidana korupsi, kolusi dan nepotisme tidak hanya dilakukan oleh penyelenggara negara, antarpenyelenggara negara, melainkan juga penyelenggara negara dengan pihak lain seperti keluarga, kroni, dan para pengusaha, sehingga merusak sendisendi kehidupan bermasyarakat, berbangsa dan bernegara, serta membahayakan eksistensi negara. Masyarakat belum sepenuhnya berperan serta dalam menjalankan fungsi kontrol sosial yang efektif terhadap penyelenggaraan negara. Dalam rangka penyelamatan dan 
normalisasi kehidupan nasional sesuai tuntutan reformasi diperlukan kesamaan visi, persepsi, dan misi dari seluruh Penyelenggara Negara dan masyarakat. Kesamaan visi, persepsi, dan misi tersebut harus sejalan dengan tuntutan hati nurani rakyat yang menghendaki terwujudnya Penyelenggara Negara yang mampu menjalankan tugas dan fungsinya secara sungguh-sungguh, penuh rasa tanggung jawab yang dilaksanakan secara efektif, efisien, bebas dari korupsi, kolusi dan nepotisme.

Pengaturan tentang peran serta masyarakat dalam undang-undang ini dimaksud untuk memberdayakan masyarakat dalam rangka mewujudkan penyelenggaraan negara yang bersih dan bebas dari korupsi, kolusi, dan nepotisme. Dengan hak dan kewajiban yang dimiliki, masyarakat diharapkan dapat lebih bergairah melaksanakan kontrol sosial secara optimal terhadap penyelenggaraan negara, dengan tetap menaati rambu-rambu hukum yang berlaku.

\section{d. Penjelasan Pasal 3}

Angka 4 Yang dimaksud dengan "Asas Keterbukaan" adalah asas yang membuka diri terhadap hak masyarakat untuk memperoleh informasi yang benar, jujur, dan tidak diskriminatif tentang penyelenggaraan negara dengan tetap memperhatikan perlindungan atas hak asasi pribadi, golongan, dan rahasia negara.

Angka 7 Yang dimaksud dengan "Asas Akuntabilitas" adalah asas yang menentukan bahwa setiap kegiatan dan hasil akhir dari kegiatan Penyelenggara Negara harus dapat dipertanggungjawabkan kepada masyarakat atau rakyat sebagai pemegang kedaulatan tertinggi negara sesuai dengan ketentuan peraturan perundang-undangan yang berlaku. e. Penjelasan Pasal 8

Ayat (1) Peran serta masyarakat yang dimaksud disini, adalah peran aktif masyarakat untuk ikut serta mewujudkan Penyelenggara Negara yang bersih dan bebas dari korupsi, kolusi, dan nepotisme, yang dilaksanakan dengan menaati norma hukum, moral, dan sosial yang berlaku dalam masyarakat.

\section{f. Penjelasan Pasal 9}

Ayat (2) Pada dasarnya masyarakat mempunyai hak untuk memperoleh informasi tentang penyelenggaraan negara, namun hal tersebut tetap harus memperhatikan ketentuan peraturan perundangundangan yang berlaku yang memberikan batasan untuk masalahmasalah tertentu dijamin kerahasiaannya, antara lain yang dijamin oleh Undang-Undang tentang Pos dan Undang-Undang tentang Perbankan.

3) Undang-Undang Nomor 39 Tahun 1999 Tentang Hak Asasi Manusia

Secara umum undang-undang ini mengatur tentang hak yang melekat pada manusia. Namun secara khusus yang berkaitan dengan keterlibatan masyarakat dalam perumusan kebijakan diatur dalam beberapa pasal, yaitu: Pasal 43 Ayat (2) tentang hak turut serta dalam pemerintahan, Pasal 44 tentang mengajukan pendapat kepada pemerintah, dan Pasal 102 khusus berkaitan dengan perumusan kebijakan dalam pengaturan HAM. Selengkapnya pasal-pasal tersebut berbunyi:

a. Pasal 43 Ayat (2) "Setiap warga negara berhak turut serta dalam pemerintahan dengan langsung atau dengan perantaraan wakil yang dipilihnya dengan bebas, menurut cara yang ditentukan dalam peraturan perundang-undangan". 
b. Pasal 44 "Setiap orang berhak sendiri maupun bersama-sama berhak mengajukan pendapat, permohonan, pengaduan, dan atau usaha kepada pemerintah dalam rangka pelaksanaan pemerintahan yang bersih, efektif, dan efisien, baik dengan lisan maupun dengan tulisan sesuai dengan ketentuan peraturan perundang-undangan".

c. Pasal 102 mengatur bahwa "Setiap orang, kelompok, organisasi politik, organisasi masyarakat, lembaga swadaya masyarakat, atau lembaga kemasyarakatan lainnya, berhak untuk mengajukan usulan mengenai perumusan dan kebijakan yang berkaitan dengan hak asasi manusia kepada Komnas HAM dan atau lembaga lainnya".

Demikian penting tersedianya mekanisme konsultasi publik didalam pemerintahan daerah khususnya dalam pembentukan kebijakan dan peraturan ditingkat daerah, maka perlu disusun suatu peraturan daerah. Peraturan daerah yang dimaksud setidaknya berisi tentang Ketentuan Umum bahwa dalam peraturan daerah tersebut terdapat istilah-istilah. Diantara istilah yang semestinya dijabarkan dan digunakan dalam Peraturan Daerah tentang Mekanisme Konsultasi Publik yaitu Daerah, Pemerintah dan Perangkat Daerah, Publik, Konsultasi Publik, Kebijakan Publik, Mekanisme konsultasi publik, Transparansi, Partisipasi Akuntabilitas adalah setiap kegiatan dan hasil akhir dari kegiatan badan publik harus dapat dipertanggungjawabkan kepada publik sebagai pemegang kedaulatan sesuai dengan ketentuan peraturan perundang-undangan yang berlaku.

Selanjutnya berisi materi pengaturan yang setidaknya mencakup:

1. Maksud dan Tujuan

\begin{abstract}
Mewujudkan sinergi kemitraan yang bertujuan untuk membangun sistem pemerintahan yang transparan, partisipatif dan akuntabel pada publik baik dalam perencanaan, pelaksanaan maupun pengawasan melalui mekanisme konsultasi publik; Meningkatkan kesadaran publik akan peran dan tanggung jawabnya dalam meningkatkan kualitas kebijakan publik yang ditetapkan; dan Mendorong terwujudnya penyelenggaraan tata pemerintahan yang baik.
\end{abstract}

2. Perencanaan

Terdiri dari tiga bagian.

Bagian kesatu, Penyusunan. Penyusunan setiap bentuk perencanaan pembangunan dan kebijakan publik oleh badan publik harus melibatkan partisipasi publik. Partisipasi publik tersebut dilaksanakan berdasarkan asas kebebasan berpendapat mengeluarkan pikiran secara lisan dan tulisan; rasional, tepat guna dan tepat sasaran, kebebasan berpendapat serta taat hukum; Partisipasi publik bertujuan untuk; meningkatkan kualitas dari kebijakan publik yang dirumuskan dan ditetapkan dalam membangun pemerintahan yang demokratis dan partisipatif; meningkatkan kesadaran publik akan peran dan tanggung jawabnya terhadap keberhasilan penyelenggaraan pemerintahan dan pembangunan daerah.

Bagian yang kedua, Hak dan Kewajiban. Publik berhak untuk berpartisipasi dalam perumusan/ penyusunan perencanaan pembangunan dan kebijakan publik, meliputi: 
perumusan visi, misi dan rencana strategis; penyusunan program pembangunan tahunan; penyusunan APBD; penyusunan maupun revisi Tata Ruang, Tata Guna Lahan dan sebagainya; penyusunan peraturan daerah; dan proses perjanjian yang diterbitkan berdasarkan kewenangan yang dimiliki.

Bagian yang Ketiga, Tata Cara. Dalam rangka menjamin keterlibatan publik maka Badan Publik menempuh mekanisme atau tata cara tertentu. Dimulai dari penyusunan dan perencanaan draft yang disampaikan kepada publik, periode dan mekanisme tanggapan publik terhadap draft/konsep, hingga terakhir penetapan kebijakan publik.

3. Penyelenggaraan Kebijakan Publik

Terdiri dari lima bagian.

Bagian Kesatu, Pelaksanaan. Dalam melaksanakan Kebijakan publik setiap Badan Publik harus mengedepankan manajemen yang mendasarkan pada transparansi, akuntabilitas dan partisipasi publik.

Bagian Kedua, Hak dan Kewajiban. Publik berhak untuk memperoleh informasi tentang pelaksanaan dan pengawasan pelaksanaan kebijakan publik berdasarkan peraturan perundang-undangan. Badan Publik wajib memelihara dan mengembangkan budaya transparansi sebagai perwujudan akuntabilitas publik untuk tercapainya tata pemerintahan yang baik.

$$
\text { Bagian }
$$

Ketiga, Informasi. Setiap proses perumusan kebijakan dan hasil kebijakannya

diinformasikan secara aktif pada publik dengan prosedur dan mekanisme tertentu. Badan Publik wajib menyediakan informasi publik setiap saat. Pemenuhan kebutuhan informasi oleh publik harus dapat diberikan dalam waktu selambat-lambatnya 1 (satu) minggu setelah permintaan. Setiap badan publik dikecualikan dari kewajiban membuka akses bagi setiap orang untuk mendapatkan informasi publik terhadap informasi yang dapat menghambat proses penegakan hukum

Bagian Keempat, Prosedur. Segala prosedur yang berkaitan dengan aspek pelayanan umum harus dilakukan dengan transparan

Bagian Kelima, Kebijakan Publik. Segala bentuk keputusan dan laporan hasilhasil rapat harus dapat diketahui oleh publik.

4. Pengawasan

Pengawasan

penyelenggaraan badan publik terdiri dari pengawasan fungsional, pengawasan legislatif dan pengawasan publik. Pengawasan fungsional dilakukan oleh Kepala Daerah. DPRD melakukan Pengawasan Legislatif atas pelaksanaan kebijakan Pemerintah Daerah. Publik dapat melakukan pengawasan terhadap penyelenggaraan Kebijakan Publik oleh Badan Publik sepanjang tidak bertentangan dengan Peraturan Perundangundangan.

5. Keberatan Publik 
Setiap pemohon informasi dan partisipasi dapat mengajukan keberatan dalam hal tertentu. Keberatan diajukan kepada atasan dari pejabat badan publik terkait.

6. Sanksi

Ketentuan pengenaan sanksi. Setiap pejabat pada Badan Publik dan/atau Publik yang tidak melaksanakan ketentuan dalam Peraturan Daerah dalam rangka Penyelenggaraan Kebijakan Publik akan dikenakan sanksi sesuai dengan peraturan perundang-undangan yang berlaku.

7. Ketentuan Lain-Lain

\begin{tabular}{lr}
\multicolumn{1}{c}{ Badan } & $\begin{array}{r}\text { Publik } \\
\text { untuk }\end{array}$ \\
berkewajiban & peningkatan \\
memfasilitasi & kelembagaan \\
kemampuan dalam & rangka \\
Publik sinergi \\
meningkatkan & seng \\
kemitraan sepanjang memenuhi \\
kriteria yang ditetapkan.
\end{tabular}

Dengan tersedianya suatu peraturan daerah yang mengatur tentang mekanisme konsultasi publik maka keterlibatan masyarakat dalam perumusan kebijakan daerah dan pembentukan peraturan di tingkat daerah menjadi jelas dengan bentuk mekanisme konsultasi publik yang memiliki payung hukum. Maka orientasi pengaturan hukum mekanisme konsultasi publik dilakukan dengan maksud dan tujuan mewujudkan sinergi kemitraan yang bertujuan untuk:

1. Membangun sistem pemerintahan yang transparan, partisipatif dan akuntabel pada publik baik dalam perencanaan, pelaksanaan maupun pengawasan melalui mekanisme konsultasi publik;

2. Meningkatkan kesadaran publik akan peran dan tanggung jawabnya dalam meningkatkan kualitas kebijakan publik yang ditetapkan; dan

3. Mendorong terwujudnya penyelenggaraan tata pemerintahan yang baik.

Terbentuknya peraturan daerah tentang mekanisme konsultasi publik sudah tepat dan untuk itu harus mengandung substansi berikut:

1. Partisipasi publik tersebut dilaksanakan berdasarkan asas kebebasan berpendapat mengeluarkan pikiran secara lisan dan tulisan: rasional, tepat guna dan tepat sasaran, kebebasan berpendapat serta taat hukum;

2. Partisipasi publik bertujuan untuk meningkatkan kualitas dari kebijakan publik yang dirumuskan dan ditetapkan dalam membangun pemerintahan yang demokratis dan partisipatif; dan

3. Meningkatkan kesadaran publik akan peran dan tanggung jawabnya terhadap keberhasilan penyelenggaraan pemerintahan dan pembangunan daerah.

\section{Kesimpulan}

Berdasarkan pembahasan dan analisa pada bab sebelumnya, maka dapat disimpulkan bahwa adanya mekanisme konsultasi publik dalam perumusan kebijakan daerah dan peraturan ditingkat daerah sangat penting untuk membangun partisipasi publik. Akuntabilitas dan transparansi penyelenggaraan pemerintahan yang mengacu pada ketentuan peraturan 
perundangan yang berlaku akan menjadi sebuah prasyarat bagi partisipasi publik yang lebih intensif yang akan semakin meningkatkan kesadaran publik akan peran dan tanggungjawabnya dalam ikut menentukan keberhasilan penyelenggaraan pemerintahan dan perwujudan tata pemerintahan yang baik. Sinergi tersebut didasarkan pada prinsip kesetaraan, partisipasi, transparansi, akuntabilitas, demokratis saling menghormati sehingga pembangunan sistem pemerintahan yang lebih baik di daerah dapat segera diwujudkan. Mekanisme konsultasi publik juga sesuai dengan pembentukan hubungan timbal balik positif antara pemerintah daerah dan masyarakat. Hal ini dikarenakan penyelenggaraan otonomi daerah yang nyata dan bertanggung jawab di daerah memerlukan peran serta aktif dan nyata dari segenap komponen penyelenggaraan pemerintahan dan pembangunan. Untuk itu, agar bentuk mekanisme konsultasi publik dapat berlaku efektif hendaknya diatur dalam suatu peraturan daerah, dengan substansi minimal yang diatur mencakup teknis pelaksanaan konsultasi publik.

Tersedianya mekanisme konsultasi publik mengharuskan lembaga publik di daerah untuk lebih terbuka, oleh karena itu penting adanya penyesuaian institusi kelembagaan daerah. Mekanisme konsultasi publik hendaknya dapat dimaksimalkan oleh masyarakat untuk terlibat aktif dalam pembentukan kebijakan dan peraturan ditingkat daerah yang sesuai dengan aspirasi masyarakat.

\section{Daftar Pustaka}

Cheema, Shabbir G, dan Rondinelli, Decentralizaytion
Development, Policy Implementation in Developing Countries, Beverly Hills, California, Sage Publications, 1984.

John Plamenatz, Democracy and Illusion, (New York: Longman, 1976).

Leo Agustio, Dasar-dasar Kebijakan Publik, (Bandung: Alfabeta, 2008).

Lijan Poltak Sinambela, Reformasi Pelayanan Publik; teori, kebijakan, dan implementasi, (Jakarta: Bumi Aksara, 2007).

Miftah Thoha, Birokrasi dan Politik di Indonesia, (Jakarta: Rajagrafindo Persada, 2003).

Miriam Budiardjo, Dasar-Dasar Ilmu Politik, (Edisi Revisi), (Jakarta: PT Gramedia Pustaka Utama, 2008)

Fungsi Legislatif dalam Sistem Politik Indonesia, (Jakarta: Rajawali Press, 1995)

Muhammad Agus Yusoff dan Rusman Ghazali, Otonomi Daerah, Partisipasi, dan Good Governance. Jurnal Ilmu Sosial dan Ilmu Politik LABSOSPOL FISIP - UNAS. 2003.

Pengantar Resensi buku Memfasilitasi Kebijakan Publik; Refleksi Pengalaman Penyusunan Rancangan Peraturan Pemerintah tentang Tahapan, Tata Cara Penyusunan, Pengendalian, dan Evaluasi Pelaksanaan Rencana Pembangunan Daerah (RPP$T 2 C P 2 E P R P D)$ yang diterbitkan oleh FPPM, BIGS, USAIDDRSP dan Dirjen Bina Bangda Depdagri. Sebagaimana dipublikasikan dalam http://jrki.wordpress.com/categor y/resensi-buku/. 
Undang-Undang Nomor 9 Tahun 1998

Tentang

Kemerdekaan

Menyampaikan Pendapat di

Depan Umum;

Undang-Undang Nomor 28 Tahun 1999 Tentang Penyelenggara Negara Yang Bersih Dan Bebas

Dari Korupsi, Kolusi Dan Nepotisme;

Undang-Undang Nomor 39 Tahun 1999 Tentang Hak Asasi Manusia;

Undang-Undang Nomor 32 Tahun 2004 tentang Pemerintahan Daerah sebagaimana telah diubah beberapa kali terakhir dengan Undang-Undang Nomor 12 Tahun 2008 tentang Perubahan Kedua Atas Undang-Undang Nomor 32 Tahun 2004 tentang Pemerintahan Daerah;

Undang-Undang Nomor 14 Tahun 2008 tentang Keterbukaan Informasi Publik;

Undang-Undang Nomor 25 Tahun 2009 Tentang Pelayanan Publik;

Undang-Undang Nomor 12 Tahun 2011 tentang Pembentukan Peraturan Perundang-undangan; 